\title{
Arion intermedius (Gastropoda: Stylommatophora); first record of this introduced slug in Chile, with notes on its anatomy and natural history
}

\author{
Arion intermedius (Gastropoda: Stylommatophora); primer registro de esta babosa \\ introducida en Chile, con notas sobre su anatomía e historia natural
}

FRANCISCO J. CÁDIZ \& CARLOS S. GALLARDO*

Instituto de Zoología Ernst F. Kilian, Facultad de Ciencias, Universidad Austral de Chile, Casilla 567, Valdivia-Chile, *e-mail for correspondence: cgallard@uach.clUT

\begin{abstract}
Results and conclusions are presented on morphological and field observations made on a collection of land slugs from the Arboretum and Botanical Garden administered by the Universidad Austral de Chile at Valdivia, as well as various records from other collection sites in southern Chile. Based on some anatomical features, the individuals studied were identified as Arion intermedius Normand, 1852, endemic to eastern Europe, and known from various locations around the world for its invasive capacity, apparently facilitated by its feeding habits and particularly by its reproductive strategy of strict self fertilization which is unusual in pulmonates. This is the first report of this species, introduced to Chile by human activities, added to previous literature citing the presence of Limacidae, Agriolimacidae, and Helicidae. This slug is a potential threat to agriculture and to native flora and fauna of Chile.
\end{abstract}

Key words: Arionidae, Arion intermedius, species introduction, invasive potential.

\section{RESUMEN}

Se entregan los resultados y conclusiones de las observaciones anatómicas y de campo realizadas sobre un grupo de babosas terrestres capturadas principalmente en el parque Arboretum y Jardín Botánico de la Universidad Austral de Chile, en la ciudad de Valdivia, además de sus hallazgos puntuales en otros puntos del sur de Chile. Los ejemplares analizados corresponden a Arion intermedius Normand, 1852, especie endémica del este de Europa conocida en diversos lugares del mundo por su alta capacidad de colonización e invasión, ello aparentemente facilitado por su hábito de alimentación y particularmente su inusual estrategia reproductiva dentro de los pulmonados (autofecundación estricta). De esta manera, registramos una nueva especie introducida antrópicamente en Chile, sumándose de esta forma la familia Arionidae a las ya conocidas Limacidae, Agriolimacidae y Helicidae como una potencial amenaza a la agricultura y a la flora y fauna nativas chilenas.

Palabras clave: Arionidae, Arion intermedius, introducción antrópica, potencial invasivo.

\section{INTRODUCTION}

The phenomenon of introduction of exotic species to new habitats by man has become increasingly serious in recent decades, mainly due to the expansion of world trade. Important agricultural pests are often transferred inadvertently among seeds, harvests, fruits or by machinery. If these species are successful in becoming established within a peviously unaffected country, they may be capable of causing serious economic damage (Hausdorf
2002). Some snail species, particularly the carnivores, are known for their deleterious effects on endemic terrestrial snails, in some cases rapidly exterminating local species. The introduction of non-endemic species needs to be prevented to avoid these problems (Robinson 1999). In any case, if an exotic species is able to establish itself in a country, its identification is the first step in evaluation of its potential impact. If necessary, subsequent steps may be required in application of appropriate control measures (Hausdorf 2002). 
Live individuals of the terrestrial slug Arion intermedius Normand, 1852 were found during field collecting at the Botanical Garden of the Universidad Austral de Chile (UACh) at Valdivia, as well as in informal collections at Arboretum Park of the UACh, the Valdivian Coastal Reserve, the "El Bosque" Urban Park and along the edge of Highway Route S-91 (Loncoche to Villarrica, Cautín Province). Arion intermedius is an herbivorous terrestrial gastropod (Bohan et al. 2000), native to eastern Europe (Kerney et al. 1983). Its introduction has been reported in North and South America, as well as to Africa, Australia, and New Zealand (Chichester \& Getz 1969, Barker 1982, 1999, Smith 1989, Robinson 1999, Hausdorf 2002). The main diagnostic characters for slugs of the Family Arionidae, within the Stylommatophora, is the absence of a dorsal keel, distal end of the foot rounded from the dorsal aspect, and pneumostome located in the mid-anterior portion of the mantle on the right side of the specimen (Burch 1962).

For consumers such as the herbivores, environmental heterogeneity in quality food resources can structure the population within a determinate space (McLaughlin \& Roughgarden 1992, Hambäck et al. 1998). Thus if we are able to learn the spatial stucture of a population of herbivores with respect to the availability of food (plants in this case) it may be possible to infer the preferences and feeding range of the species which can elucidate its capacity for invasiveness and thus the ecological implications of its introduction. Based on this concept we made a survey of the Botanical Garden at UACh to determine the plant species with which this species was associated and the origin, whether native of introduced, of the plant involved. The present report documents these findings, supported by identifications based on diagnostic morphology and meristic data from the samples obtained. Based on the results of the present analyses, we discuss the potential impact of successful adaptation and subsequent dispersion that this species may have on native environments.

\section{MATERIAL AND METHODS}

Samples of the slug were collected on various occasions between September 2005 and August
2006, searching in mosses, under leaf litter and rotting $\log \mathrm{s}$ in the Botanical Garden of the UACh at Valdivia $\left(39^{\circ} 48^{\prime} \mathrm{S} ; 73^{\circ} 14^{\prime} \mathrm{W}\right)$, Arboretum Park UACh $\left(39^{\circ} 48^{\prime} \mathrm{S} ; 7^{\circ} 15^{\prime} \mathrm{W}\right)$, the Valdivian Coastal Reserve (39 $57^{\prime} \mathrm{S}$; $\left.73^{\circ} 34^{\prime} \mathrm{W}\right)$, the El Bosque Urban Park (39 $50^{\circ}$ $\left.\mathrm{S} ; 73^{\circ} 14^{\prime} \mathrm{W}\right)$ and along the edge of highway route S-91 ( $\left.39^{\circ} 17^{\prime} \mathrm{S} ; 72^{\circ} 24^{\prime} \mathrm{W}\right)$.

The slugs were collected and individually identified and weighed and the sample locations were recorded. Subsequent observations were made on details of the internal and external morphology of the specimens, including the reproductive system and color patterns, with aid of a Lavovert FS® stereoscopic microscope. Illustrations were made with the help of digital photographs of specimens taken through this microscope

The affinities of the slugs for different plant species were studied at the UACh Botanical Garden in August 2006, examining four floristically varied areas, including sites having native vegetation and sites with introduced vegetation (Table 1 ). Soil samples of $25 \times 25 \times$ $10 \mathrm{~cm}$ (length $\mathrm{x}$ width $\mathrm{x}$ depth) (Bohan et al. 2000) were taken to the laboratory, where the absolute density of the slugs was determined. The slugs were extracted from the soil samples by gradual flooding (Symondson et al. 1996), thus forcing them to the soil surface, where they were collected daily. The specimens were recognized and described following the morphotypes described for this species by Backeljau et al. (1992), based on the color patterns evident on different regions of the body. Samples of our specimens are currently deposited in the Malacology Collection of the Institute of Zoology, Universidad Austral de Chile, Valdivia.

TABLE 1

Details of the plant species involved in the sampling carried out in the UACh Botanical Garden

Detalle de las especies vegetales involucradas en los muestreos realizados en el Jardín Botánico UACh

\begin{tabular}{lccc}
\hline Site & Species & Family & Origin \\
\hline 1 & Selaginella apoda & Selaginellaceae & Introduced \\
2 & Nertera granadensis & Rubiaceae & Native \\
3 & Thuidium chilense & Thuidiaceae & Native \\
4 & Trifolium pratense & Fabaceae & Introduced \\
\hline
\end{tabular}




\section{RESULTS}

External observations of the specimens showed characteristics of the family Arionidae (Burch 1962), including rounded terminal portion of the foot in the dorsal perspective, absence of a dorsal keel, and the pneumostome situated in the mid-anterior region of the mantle, on the right side (Fig. 1 and 2). Further characteristic, detailed below, identified the species to be Arion intermedius Normand, 1852 (sensu Pilsbry 1948, Likharev \& Wiktor 1980, Kerney et al. 1983, Barker 1999, Wiktor 2000) (Fig. 3).



Fig. 1: (A) Extreme distal portion (dorsal view) of Limax sp.; (B) same view of Arion intermedius. Note the pointed aspect and dorsal keel of (A) compared with the rounded aspect, and absence of dorsal keel of (B). $\mathrm{Kl}=$ dorsal keel, $\mathrm{Rb}=$ rounded back, $\mathrm{Ft}=$ foot.

Extremo posterior (vista dorsal) de Limax sp. (A) y de Arion intermedius (B). Nótese el extremo aguzado y con una quilla dorsal en Limax sp. y el extremo posterior redondeado y carente de quilla dorsal de A. intermedius. $\mathrm{Kl}=$ quilla dorsal; $\mathrm{Rb}=$ dorso redondeado; $\mathrm{Ft}=$ pie. 




Fig. 2: (A) Extreme anterior right side of Limax sp. Location of the pneumostome in Limax sp. is in the posterior half of the mantle, whereas in A. intermedius (B) this structure is in the anterior half mantle region. $\mathrm{Mt}=$ mantle, $\mathrm{Pn}=$ pneumostome, $\mathrm{Ft}=$ foot .

(A) Extremo anterior (vista lateral derecha) de Limax sp.; el pneumostoma en Limax sp. está ubicado en la mitad posterior del manto, al contrario de A. intermedius, en la cual este se encuentra en la mitad anterior. Mt: manto; Pn: pneumostoma; Ft: pie.

\section{Systematic position of the species}

The original classification follows Haszprunar \& Huber (1990); to levels of superfamily and to family we followed Hubendick (1978): Class Gastropoda Cuvier, 1795; Subclass
Pulmonata Cuvier, 1814; Order Eupulmonata Haszprunar \& Huber, 1990; Suborder Stylommatophora Pilsbry, 1948; Superfamily Arionoidea Gray, 1840; Family Arionidae Gray, 1840; Arion intermedius Normand, 1852 . 


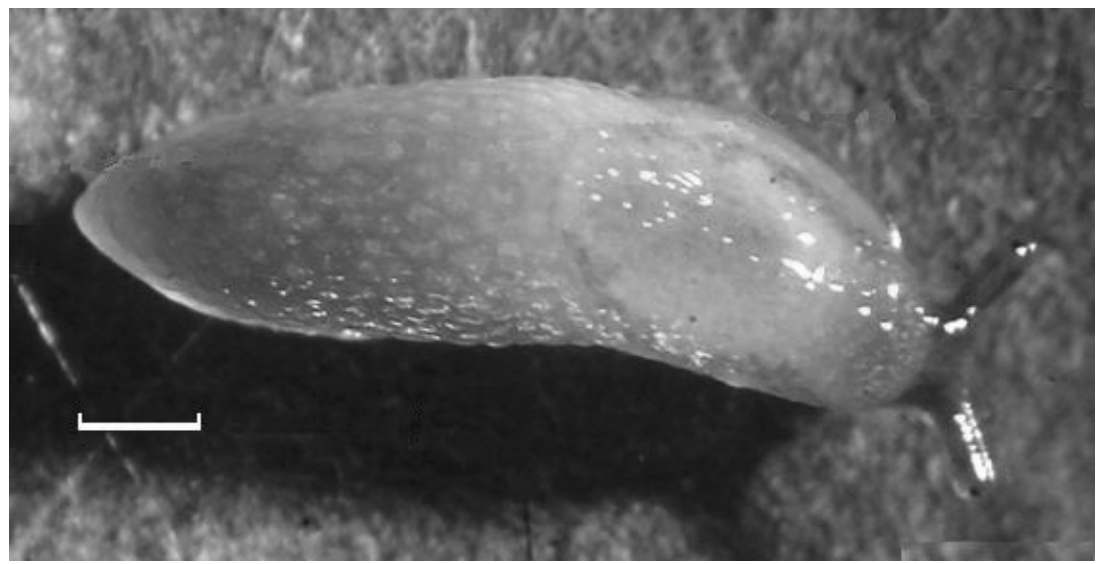

Fig. 3: Juvenile of Arion intermedius, dorsal view. Scale bar: $1 \mathrm{~mm}$.

Ejemplar juvenil de Arion intermedius, vista dorsal. Escala: $1 \mathrm{~mm}$.

TABLE 2

Results of samplings carried out in the UACh Botanical Garden. In addition to the total number of specimens (n) obtained in each sampling are listed the range in values, mean $( \pm$ SD) both for the lengths and weights of the specimens

Resultados de los muestreos realizados en el Jardín Botánico UACh. Se indica en cada muestreo, además del número de individuos (n), el rango de los valores, su promedio ( \pm DE) tanto para la longitud como los pesos de los especímenes

\begin{tabular}{lccccc}
\hline Site & $\mathrm{n}$ & Specimen size range $(\mathrm{mm})$ & Mean size $(\mathrm{mm})$ & Specimen weight range $(\mathrm{g})$ & Mean weight $(\mathrm{g})$ \\
\hline 1 & 7 & $11.5-15.3$ & $13.3 \pm 1.3$ & $0.025-0.0423$ & $0.0343 \pm 0.0073$ \\
2 & 3 & $10.5-10.9$ & $11 \pm 0.6$ & $0.0222-0.032$ & $0.046 \pm 0.0059$ \\
3 & 12 & $5.6-14.5$ & $9.6 \pm 2.9$ & $0.0072-0.0352$ & $0.0162 \pm 0.0089$ \\
4 & 3 & $8.9-14.1$ & $10.8 \pm 2.9$ & $0.0104-0.0593$ & $0.0279 \pm 0.0272$ \\
\hline
\end{tabular}

Morphometric characteristics and structures of taxonomic value

The results obtained with specimens collected at the UACh Botanical Garden are presented in Table 2. The sampled individuals had a minimum size of $5.6 \mathrm{~mm}$ (Sample 3) and the maximum was $15.3 \mathrm{~mm}$ (Sample 1) as measured from the tips of the upper tentacles to the end of the foot; the overall average (Samples 1 to 4 ) was $11 \pm 2.7 \mathrm{~mm}$.

\section{External morphology}

The A. intermedius specimens from the UACh Botanical Garden represented morph "Y" of Backeljau et al. (1992). The same was observed for all other samples from the different collecting sites. This morphotype was uniformly yellowocre in color, with mantle and dorsum lacking a black center and dark spots. The border of the foot was yellowish and weakly lined. The ventral surface of the foot was whitish to yellow.

\section{Reproductive system}

Spatial arrangement and identification of the main structures in the reproductive system of $A$. intermedius are presented in Fig. 4. Adult specimens were recognizeable from the notably swollen seminal vesicle, indicating storage of mature spermatozoa. No spermatophores were encountered in the bursa copulatrix of the adult specimens examined. 




Fig. 4: Reproductive system of Arion intermedius. 01, body wall; 02, genital atrium; 03, phallus; 04, epiphallus; 05, vagina; 06, vas deferens; 07, bursa copulatrix; 08, oviduct; 09, prostatic gland; 10, albumin gland; 11, hermaphroditic duct; 12, ovotestis. Scale bar: $2.5 \mathrm{~mm}$.

Sistema reproductor de Arion intermedius. 01, pared del cuerpo; 02, atrio genital; 03, falo; 04, epifalo; 05, vagina; 06, vaso deferente; 07, bursa copulatriz; 08, oviducto; 09, glándula prostática; 10, glándula del albumen; 11, ducto hermafrodita; 12, ovotestis. Escala: $2,5 \mathrm{~mm}$.

\section{Radula}

The morphology of the radular dentition is shown in Fig. 5. The radula is composed of three types of teeth arranged linearly, including central teeth (CT), lateral teeth (LT), and marginal teeth (MT). The basal plate of the first lateral tooth is observed to be about $1 / 4$ higher than central tooth plate. This arrangement is repeated with the second lateral tooth with respect to the first, with teeth then continuing at the same height until the last marginal tooth. The CT is tricuspid, with a lanceolate, elongated mesocone, with its extreme distal portion reaching the first quarter of the following CT plate. The lateral cuspids are of similar size, approximately $1 / 2$ the size of the mesocone. The LT are distributed laterally to the CT, are bicuspid, and have an ectocone in regression. The mesocone is lanceolate and perpendicular to its base, and 1/8 larger than its sustaining plate. Its ectocone represents about $1 / 2$ the length of the mesocone. The MT appears as a continuation of the 14-15 LT, with a configuration similar to those of the LT. They are bicuspid, and have an ectocone in regression, but with a marked inclination of the mesocone toward the center of the radula. This inclination becomes increasingly apparent as the MT extend toward the lateral limit of the radula.

Radular formula: C/1 + L14-15/2 + M15-16/2 


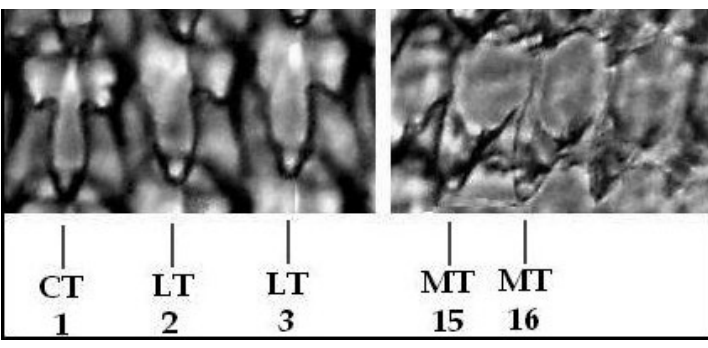

Fig. 5: Scheme of the tooth morphology in $A$. intermedius radula. $\mathrm{CT}=$ central tooth $; \mathrm{LT}=$ lateral teeth; MT = marginal teeth. The numbers under the abbreviations indicate the positions of the teeth in the radular scheme (see text).

Esquema de la morfología dentaria en rádula de Arion intermedius. CT: diente central; LT: dientes laterales; MT: dientes marginales. Los números bajo las abreviaciones indican la posición de dichos dientes en el esquema radular (ver texto).

\section{Associations with plants}

Individuals of this slug were found in all the soil samples examined with no differences related to the origins of the plants on the plots sampled in the Botanical Garden. The frequency, sizes and weights of the specimens found at each site are presented in Table 2.

\section{DISCUSSION}

Nine terrestrial gastropods have been reported as introduced species in Chile (Stuardo \& Vega 1985, Valdovinos 1999). They include Milax gagates (Drapanaurd, 1801); Deroceras reticulatum (Müller, 1774); Deroceras laeve (Müller, 1774); Limax valentianus Férussac, 1821; Limax maximus Linnaeus, 1758; Limax flavus Linnaeus, 1758; Oxychilus cellarius (Müller, 1822); Oxychilus alliarius (Müller, 1822); Helix aspersa Müller, 1774. Of these, the genera Milax, Deroceras, Limax, and Helix are known to be potentially damaging to agriculture (Hausdorf 2002. The family Arionidae, and specifically the genus Arion are considered potentially damaging for agriculture according to international organizations concerned with plague control such as CAPS (Eastern Region Cooperative Agricultural Pest Survey) (TUhttp://www.invasive.org)UT.
In general, environments altered by human activities are often areas of invasion by exotic species of snails and slugs (Hausdorf 2002). In this respect, Arion intermedius is an exception, since this species has a greater capacity for penetration into unaltered native forests than do other introduced species which have been reported and studied in North America (Chichester \& Ges 1969), Australia (Smith 1981), New Zealand (Barker 1982), and Colombia (Hausdorf 2002). In the case of Valdivia, and in accordance with our results of analysis at the UACh Botanical Garden, this species was found strongly associated with mosses such as Thuidium chilense (Mitten, 1869), and plants such as Nertera granadensis (Mutis ex Lf), which are native species broadly distributed through the south Chilean ecosystem. In the case of the "El Bosque" Urban Park, specimens were found living six meters above ground level on Laurelia sempervirens (Monimiaceae), a tree species widely distributed in Chile. When we note that A. intermedius has been identified as the slug associated with the highest rate of decomposition of organic leaf litter among several slug species (Jennings \& Barkham 1979), its possible impact on systems dependent on the accumulation of thick horizons of leaf litter cannot be ignored. In Arboretum Park, for example, we found A. intermedius to be well established in places normally occupied by endemic molluscs such as Plectostylus sp., and microgastropods such as Stephanoda mirabilis Scott 1968, Austrodiscus sp. and Radiodiscus sp., which are very small species whose biology is poorly known. It is possible that $A$. intermedius may produce negative effects on the local species of terrestrial gastropods, potentially effecting their ecological displacement.

On the other hand, the reproductive strategy of this slug (self-fertilization, probably strict) (Mccracken \& Selander 1980, Backeljau \& De Bruyn 1990, Reise et al. 2001) allows even one individual to begin colonizing a new habitat, accentuating its invasive capacity.

It would be a difficult, perhaps impossible task to ascertain the history of introduction of this species into Chile. The long distance between specimens collected between Route S91 and the Valdivian Coastal Reserve (124 $\mathrm{km}$.) indirectly suggests that the introduction 
has not been recent. Conversely, if it had been introduced recently, its dispersal has occurred rapidly, probably transported unnoticed in human activities, since the species is highly limited in migrational capacity in comparison with similar species (Bohan et al. 2000). In this case, an effect of propagation promoted by human activity would be accentuated due to the slug's capacity for reproduction by selffertilization (a rare case among pulmonates) and thus having a high degree of ability to colonize in spite of occurring at low density (Selander \& Ochman 1983, Jarne \& Charlesworth 1993).

It is of prime importance to monitor the extent of impacts which may be produced by the interaction of this species with native species, and if necessary, take preventive measures for reducing or reversing them. Perhaps more stringent border control needs to be exercised with seeds, harvests, fruits, and machinery, in order to avoid the possibility of similar situations occurring in the future with other exotic species.

\section{ACKNOWLEDGEMENTS}

We thank to the administrative staff of the Valdivian Coastal Reserve (the Nature Conservancy), and to Mario Maturana (manager of "El Bosque" Urban Park), for facilities provided at the field studies. Our thanks also to Guilorma Sandoval for valuable help to the first author during sampling of animals and field studies. Part of this research and preparation of the MS were financially supported through Project DID UACH 2005-12 to the second author.

\section{LITERATURE CITED}

BACKELJAU T \& L DE BRUYN (1990). On the infrageneric systematics of the genus Arion Férussac, 1819 (Mollusca, Pulmonata). Bulletin de 1'Institut Royal des Sciences Naturelles de Belgique, Biologie 60: 35-68.

BACKELJAU T, C DE BRITO, RM TRISTÃO \& AM FRIAS (1992). Colour polymorphism and genetic strains in Arion intermedius from Flores, Azores (Mollusca: Pulmonata). Biological Journal of the Linnean Society 46: 131-143

BARKER GM (1982) Notes on the introduced terrestrial Pulmonata (Gastropoda: Mollusca) of New Zealand. Journal of Molluscan Studies 48: 174-181.
BARKER GM (1999) Naturalised terrestrial Stylommatophora (Mollusca:Gastropoda). In: Crosby $\mathrm{T}$ (ed) Fauna of New Zealand 38: 5-253. Manaaki Whenua Press, Lincoln, New Zealand.

BOHAN DA, DM GLEN, CW WILTSHIRE \& L HUGHES (2000) Parametric intensity and the spatial arrangement of the terrestrial mollusc herbivores Deroceras reticulatum and Arion intermedius. Journal of Animal Ecology 36: 1031-1046.

BURCH JB (1962) How to know: the eastern land snails. Wm. C. Brown Company Publishers, Dubuque, Iowa, USA. 214 pp.

CHICHESTER LF \& LL GETZ (1969) The zoogeography and ecology of arionid and limacid slugs introduced into northeastern North America. Malacologia 7: 313-346.

GARRIDO C, J CASTILLEJO \& J IGLESIAS (1995) The spermatophore of Arion intermedius (Pulmonata: Arionidae). Journal of Molluscan Studies 61: 127133.

HAMBÄCK PA, M SCHNEIDER \& T OKSANEN (1998) Winter herbivory by voles during a population peak: the relative importance of local factors and landscape pattern. Journal of Animal Ecology 67: 544-553.

HAUSDORF B (2002) Introduced land snails and slugs in Colombia. Journal of Molluscan Studies 68: 127 131.

HAZPRUNAR G \& G HUBER (1990) On the central nervous system of Smeagolidae and Rhodopidae, two families questionably allied with the Gymnomorpha (Gastropoda: Euthyneura). Journal of Zoology London 220: 185-199.

HUBENDICK B (1978) Systematics and comparative morphology of the Basommatophora. In: Fretter V \& JF Peake (eds) Pulmonates Volume 2A: systematics, evolution and ecology: 1-47. Academic Press, London, United Kingdom.

JARNE P \& D CHARLESWORTH (1993) The evolution of the selfing rate in functionally hermaphrodite plants and animals. Annual Review of Ecology and Systematics 24: 441-466.

JENNINGS TJ \& JP BARKHAM (1979) Litter decomposition by slugs in mixed deciduous woodland. Holarctic Ecology 2: 21-29.

KERNEY MP, RA CAMERON \& JH JUNGBLUTH (1983) Die Landschnecken Nord - und Mitteleuropas. Paul Parey, Hamburg, Germany. 384 pp.

LIKHAREV IM \& AJ WIKTOR (1980) Slizni fauny SSSR i sopredelnych stran (Gastropoda terrestria nuda). Fauna SSSR, Molljuski , III (5). Nauka, Leningrad, Russia. 437 pp.

MCCRACKEN GF \& SELANDER RK (1980) Selffertilization and monogenic strains in natural populations of terrestrial slugs. Proceedings of the National Academy of Sciences of the United States of America 77: 684-688.

MCLAUGHLIN JF \& J ROUGHGARDEN (1992) Species interactions in space. In: Ricklefs RE \& D Schuster (eds) Species diversity in ecological communities: historical and geographical perspectives: 89-98. University of Chicago Press, Chicago, Illinois, USA.

PILSBRY HA (1939-1948) Land mollusca of North America (North of Mexico), 1-2. Academy of Natural Science of Philadelphia, Monograph 3. ANS, Philadelphia, USA.

REISE H, B ZIMDARS, $K$ JORDAENS \& $T$ BACKELJAU (2001) First Evidence of Possible 
Outcrossing in the Terrestrial Slug Arion Intermedius (Gastropoda: Pulmonata). Hereditas 134: $267-270$

ROBINSON DG (1999) Alien invasions: the effects of the global economy on non- marine gastropod introductions into the United States. Malacologia 41: 413-438.

SELANDER RK \& H OCHMAN (1983) The genetic structure of populations as illustrated by molluscs. Isozymes 10: 93-123.

SMITH BJ (1981) Introduced non-marine molluscs in Australia. Victorian Naturalist 98: 24-27.

SMITH BJ (1989) Travelling snails. Journal of Medical and Applied Malacology 1: 195-204.

STUARDO J \& R VEGA (1985) Synopsis of the land mollusca of Chile, with remarks on distribution.

Associate Editor: Patricio Camus

Received February 23, 2006; accepted September 30, 2006
Studies on Neotropical Fauna and Environment 20: 125-146.

SYMONDSON WO, DM GLEN, CW WILTSHIRE, CJ LANGDON \& JE LIDDELL (1996) Effects of cultivation techniques and methods of straw disposal on predation by Pterostichus melanarius (Coleoptera: Carabidae) upon slugs (Gastropoda: Pulmonata) in an arable field. Journal of Applied Ecology 33: 741-753.

VALDOVINOS C (1999) Biodiversidad de moluscos chilenos: base de datos taxonómica y distribucional. Gayana (Chile) 63: 111-164.

WIKTOR A (2000) Agriolimacidae (Gastropoda; Pulmonata) - a systematic monograph. Annales Zoologici, Warszawa (Poland) 49: 347-590. 
